\section{THE CASE OF THE LATE MR. ALFRED BOURNE.}

To the Editors of THE LANCBT.

SIRS,-We shall be obliged, and it will be an act of charitable kindness, if you will be good enough, thmough the columns of THE LANCET, to give publicity to this appeal to the medical profession on behalf of the widow and children of the late Mr. A. Bourne, surgeon, Osmotherley, Yorkshire. Mrs. Bourne, with six young children, by the unexpected and sudden death of her husband at the age of 37 years, has been left totally unprovided for, with no friends who are in a position to give the necessary help. Subscriptions will lie thankfully received and acknowledged in the columns of THE LANCET by the undersigned.

We are, Sirs, yours faithfully,

J. A. Hutcinnson, M.D. Durh., Northallerton.

WiLliaM BAIgENT, M.D. Durh., Northallerton.

Thomas YermaN, J.P., Osmotherley.

WM. DoBson, J.P., Osmotherley.

WM. Bovinle, Northallerton.

Northallerton, Yorkshire, May 9th, 1900.

\section{"SEPTIC THROMBOSIS OF THE CATERNOUS SINUS."}

To the Editors of THE LANCET.

SiRS, - In an annotation in THE LANCET of May 5th (p. 1298) you record a case of septic thrombosis of the cavernous sinus which arose from a tooth abscess. Perhaps the following notes of a similar case may serve to emphasise the possibility of so common an affection as toothache having so serious a sequel. On June 5th of last year a girl, aged 18 years, came to the casual department of the Newcastle Royal Infirmary complaining of toothache with swollen face of two weeks' duration. She looked ill, there was a large tender swelling over the left side of the lower jaw, and she was unable to open her mouth. Under chloroform anæsthesia the mouth was opened with a gag and two very carious loose lower molars were removed from the left side, a large quantity of very fotid pus escaped into the mouth, and as the abscess was apparently freely opened an incision into the swelling from the outside was purposely avoided. The girl was given a mouth-wash and fomentation to apply to her oheek. At this time her temperature was not taken; there was no proptosis or other sign of grave mischief. I thought she had only a large alveolar abscess which would soon get well and allowed her to go home. Two days later, on June 7th, the girl came back. She was exceedingly ill, the temperature was $104^{\circ} \mathrm{F}$., and the pulse was correspondingly rapid. There was very marked proptosis of the right eye with oedema of the lids and conjunctiva and fixidity of the eyeball. The swelling over the jaw had subsided and pus was discharging freely into the mouth. She complained of very severe headache. An incision was made through the conjunctiva over the eye, and a pair of sinus forceps was passed to the back of the orbit, but only a little thin pus escaped. She was given anti-streptococcic serum. Next day she was very much worse; her temperature was $104^{\circ}$ and there were retraction of the neck and vomiting, with a very marked meningitis cry. An abscess over the left ascending ramus of the jaw was opened; the upper and lower jaw-bones were felt to be quite bare. The patient got rapidly worse and died next day (June 9th) with a temperature of $104 \cdot 6^{\circ}$. She had no rigors and there were no signs of cavernous thrombosis on the left side. At the post-mortem examination there were marked septic basal meningitis and septic thrombosis of botb cavernous sinuses; on the right side the orbital veins were thrombosed and there was orbital cellulitis on the left side; the orbital contents were healthy; both lateral sinuses were filled with septic clots. The left pterygoid region was filled with necrosed septic tissue and pus had found its way into the skull tbrough both the foramen ovale and foramen rotundum. There was a good deal of pus in the left temporal muscle sheath and the periosteum was entirely stripped from both upper and lower jaws on the affected side. I have now little doubt that when the girl came to the Infirmary first she was much more seriously ill than I then supposed her to be. Apart from the practical importance of the case as illustrating an unusual cause of an unusual condition it is difficult to explain why the thrombosis should bave been more extensive on the right side which was presumably fartbest away from the primary focus. While the patient was in the Infirmary she was under the care of $\mathrm{Mr}$. Page, and it is through his kindness that I am allowed to publish this note.

I am, Sirs, yours faithfally, G. GREY TLRNER.

Royal Infirmary, Newcastle-on-Tyne, May, 1900.

\section{"DEATHS UNDER CHLOROFOR 1I." To the Editors of THE LANCET.}

Sirs,-Dr. G. Nowat's letter in THE LANCET of March 24th (p. 884) requires a few words of answer. The fact which he now intimates for the first time-namely, that death occurred during the stage of excitement-is the strongest possible proof of my contention that his original description of the case was so meagre as to be useless. Possibly he carries the same principle-the principle of sketchiness-yet further, for he seems to imagine that the clinical observation of a patient under chloroform close enough to ensure the subsequent unity of a full and accurate report of his symptoms places his life in danger. Can one argue with sach an one? The question is a much wider one than Dr. Mowat appears to conceive. Experiments on the lower animals have failed to produce any unanimity on the subject in the profession. The publication of full and accurate clinical descriptions of deaths under and from chloroform appear to afford the only prospect of such settlement; and I am not alone in thinking that here, as in other departments of medicine, general accurate knowledge will bring general confidence and increased safety. I am not among those who imagine that the saving of many lives yearly is a matter of purely scientific interest, so I repeat my appeal for full and accurate descriptions of all cases of death under chloroform. I am, Sirs, yours faithfully, Clayton Lane, M.D. Lond.

Lucknow, N.W.P., India, April 25th, 1900 . Captain, I.M.S.

\section{"A PARASITIC CRUSTACEAN AS A FOREIGN BODY ON THE CORNEA": A CORRECTION.}

\section{To the Editors of THE LANCET.}

SIRS,-In THE LANCET of April 7th, p. 1002, a very interesting condition is described by Dr. Rayner Batten of a fishmonger who had a peculiar growth on the cornea of the left eye. From this he removed a small scale-like parasite, of which a very careful and accurate drawing is given. This parasite was referred to Dr. Harmer, F.R.S.. who stated it to be one of the caligidæ, probably Caligus curtus. This is an error, as the parasite, which has kindly been sent to me by Dr. Batten, shows. Though it belongs to the caligidæ it should be placed in the genus Lepeophtheirus, distinguished from the genus Caligus by the entire absence of the two prominent lunulæ on the frontal plates. The specimen was a male of $L$. pectoralis, Müll, found very abundantly on most flatfish, particularly plaice and fiounders. These I have kept alive for hours in water in a watch-glass, but though for years in constant communication with men handling fresh fish I have never before met with one who had become the temporary host of these parasites. Dr. Harmer did not intend his diagnosis of the species for publication, but as it has appeared he quite agrees with me that the correct nomenclature should be used.

May, 1900. I am, Sirs, yours faithfully,

\section{THE HOT SPRINGS OF BATH.}

To the Editors of THE LANCET.

SIRS, - I wish to bear testimony to the magnificent efficacy of a course of these baths. The whole system of treatment is so rational and so perfectly managed and the attention and care shown so universally good tbat I am certain that there is no other treatment (except it may be the Tallerman hot-air process), combined with the drinking of the Bath hot mineral water, half so efficacions for lumbago and sciatica generally of a gouty nature.

It is unnecessary for me to enter into particulars how the douches of a temperature of $106^{\circ} \mathrm{F}$. with a force of 16 pounds and of the hot mineral baths with massage are used. 
I can only say that although I am only able to spare a fortnight to the treatment I am leaving Bath feeling in every respect pounds better. This spring, from all accounts, sciatica appears to have been epidemic. Let me say too with regard to this complaint, having twice suffered from it, that, to my mind, there are two forms, the lower and the upper. The first time I had the lower form, when the sciatic nerve from its notch down the back of the thigh gave the most agonising pain, and the outer leg and ankle were also very painful. This time I have suffered from the upper form, when the first point of pain was in the upper part of the buttock. To name rightly the nerve branch affected I should have to refer to the anatomical work of my good old teacher, Professor Vyner Ellis (so recently dead), which is at my home. From the buttock the pain has been distributed through the groin, and down the iliofemoral band to a short distance below the knee, the knee often being particularly painful.

The lower form, though the pain was continuously intense, only incapacitated me from work for ten days. The upper form of sciatica kept me in bed three weeks and three days, and then when I tried for some days to work I had to give up, the pain being too severe for me to keep up against; and now after a fortnight's treatment in Bath, though returning to work, I am still at times somewhat crippled by the pain.

For these reasons $I$ am of opinion that there are two kinds of sciatica, upper and lower, and that the upper kind is by far the worse of the two. When the lower form attacked me $I$ do not remember that $m y$ leg lost at all in size. In this attack after the first month the upper part of my thigh lost two inches in circumference.

I am. Sirs, yonrs faithfully,

Pierrepont-street, Batb, May 15tb, $1900 . \quad$ Pugin THornton.

\section{M.D. DURHAM FOR PRACTITIONERS. To the Editors of THE LANCET.}

SIRs,--Kindly allow me to answer through your columns some questions respecting the above degree. Intending candidates who have the files of THE LANCET by them will find a letter signed "M.D." on Oct. 15th, 1898, containing some sound advice. I, for one, am grateful to him for it. For those who have not the letter by them $I$ would say: write to Dr. Howden, the courteous secretary of Durham University, for a copy of the last Calendar, which gives the text-books advised and some of the recent papers given. Get the latest editions. Either the Latin or Professional may be taken separately or first. Unless Latin is an easy subject I advise taking it first and alone so as to be free for purely professional subjects. Get up thoroughly urine and urinary microscopic and pathological and histological work. If possible do some clinical work and go over a good museum once or twice. Those near London will get much help in hygiene by going over the Parkes Museum. The examination is thorough, but perfectly fair and just. 'The clinical work must be done well. Do not go up with the idea that the degree is given away or you will regret it. Remember that you are again a student undergoing examination. To those who have few opportunities I would advise them to go up eight or nine days before the examination and attend a special class for this degree which is given. They will be taken over all the work, particularly the pathological and microscopical work, which is so essential. I wish success to all intending candidates and hope they will have as much pleasure in going over the old ground as I had. After an interval of 20 years it was a great treat to be again examined by one of the kindest and most eminent of London surgeons. Operative surgery has made great strides since the day when last we met.

May 15th, 1900.

I am, Sirs, yours faithfully,

Bristol Lunatic Asylum.-The thirty-ninth annual report of this institution, which has just been issued, shows that on Dec. 31st, 1899, there were 778 patientsviz., 379 males and 399 females-in the asylum. The highest number resident at any one time in the year was 799 . The extension of the asylum buildings, with the exception of the isolation hospital, will shortly be completed and will be ready for occupation early this summer. The committee, in concluding the report, expressed their high appreciation of the manner in which the medical superintendent and the officers and staff of the asylum had performed their respective duties during 1899.

\section{THE PARIS EXHIBITION.}

(From oUr OWN Correspondent.)

THE name remains though the substance has gone. The Gallery of Machines is still known by that name though, as already explained, it no longer contains any machinery, for in its centre there is the Hall of Festivals and on each side are arranged alimentary and agricultural products. The gallery which is parallel and next to this vast and magnificent iron and glass structure does contain machinery in motion, huge boilers, power-producers, and electrical machinery. This is the most backward part of the Exhibition. Here chaos reigned supreme long after the Exhibition was opened There was bare earth where there should be carpeted boards, some portions were absolutely impassable, and the visitor was constantly turned back, first at one point and then at another, by attendants whose duty it was to prevent sightseers from incurring the risk of accident. Yet even here, by going upstairs to the galleries, there is a good deal to be seen, for Olass 112 has nearly all its exhibits in order. This class deals with poor relief and is situated close to the Hall of Festivals, and a portion of it was officially inaugurated last week. Here all private and public organisations and charities for the relief of the poor display drawings, charts, maps, models, statistical tables, \&c., that may serve to illustrate their work. Then, again, in the gardens of the Champ de Mars facing the monumental Châtean d'Eau the aspect is that of a railway goods station rather than that of pleasure-grounds. The railway lines have not been covered up and numerous railway trucks are still there, though the process of unlogd. ing them is postponed till after the grounds are closed to the public. Nor is there any immediate need to clear this space till the Château d'Eau which it faces is itself finished. This, however, is approaching completion. Nearly all the scaffolding has been removed and the sculptors are giving their final touches to the nymphs who are gracefully poised over and about the waterfalls. That the largest structure, the principal architectural feature, of the Exhibition should consist of a succession of cascades issuing from within a monumental arch is certainly a very original conception. Above and around, the gilding and the white statuary, and at night the blaze of electric light, will produce a most impressive effect; and it is only right that in front a vacant space, large enough to hold thousands and thousands of people, should have been left free of all encumbrance. This space, which at present constitutes the principal goods station of the Exhibition, will soon be clear, and when all is complete it will attract visitors who may be counted by the million.

On the westerly side of the Eiffel Tower there are still a good many buildings which are not yet finished, and here dust or mud and cobbles and sharp stones still prevail, but on the opposite side better progress bas been made. Indeed, the mason and the plasterer and scaffolding and rubbish.carts are now confined to a few corners and localities and genuine progress towards completion bas been made. Every day some new section or pavilion is finished which very often forms of itself a sufficient motive for a visit to the Exbibition. Thus, in the Avenue of Nations the vast Italian Pavilion opened its doors the week before last. Under the gilt cupola reproduced from St. Mark's of Venice and within walls that imitate those of the palace of the Doges the artistic glasswork, ceramic arts, sculpture, and mosaics, \&c., of Italy are exhibited, while in a gallery running round the building the technical schools, the universities, and the municipalities display drawings, and charts, and specimens that explain what has been done to improve the health and educa. tion of the people. Immediately behind this palace Denmark shows a model middle-class dwelling to which the public are now admitted and which illustrates the home life of that country. The Hungarian Pavilion is also completed and forms a sort of synopsis of the history and avocations of the Hungarian people. On one side there is a reconstruction of the Abbey and the Church of Jaak, and on the other side the frontage of the Vajda-Hunyad mansion and the fortress of Koermoeczbanya, together with other specimens of Hungarian architecture; while inside the arts, and sciences, and the industrial progress of that interesting people are illustrated by numerous exhibits. The Finland Pavilion is also open and here the visitor may appreciate 